\title{
Destined to die in hospital? Systematic review and meta-analysis of place of death in haematological malignancy
}

\author{
Debra A Howell*1, Eve Roman'1, Helen Cox¹, Alexandra G Smith¹, Russell Patmore², Anne C Garry³ and \\ Martin R Howard 4
}

\begin{abstract}
Background: Haematological malignancies are a common, heterogeneous and complex group of diseases that are often associated with poor outcomes despite intensive treatment. Research surrounding end-of-life issues, and particularly place of death, is therefore of paramount importance, yet place of death has not been formally reviewed in these patients.

Methods: A systematic literature review and meta-analysis was undertaken using PubMed to identify all studies published between 1966 and 2010. Studies examining place of death in adult haematology patients, using routinely compiled morbidity and mortality data and providing results specific to this disease were included. 21 studies were identified with descriptive and/or risk-estimate data; 17 were included in a meta-analysis.

Results: Compared to other cancer deaths, haematology patients were more than twice as likely to die in hospital (Odds Ratio 2.25 [95\% Confidence Intervals, 2.07-2.44]).

Conclusion: Home is generally considered the preferred place of death but haematology patients usually die in hospital. This has implications for patients who may not be dying where they wish, and also health commissioners who may be funding costly end-of-life care in inappropriate acute hospital settings. More research is needed about preferred place of care for haematology patients, reasons for hospital deaths, and how these can be avoided if home death is preferred.
\end{abstract}

\section{Background}

Haematological malignancies are common, being the fourth most frequently diagnosed cancer in both males and females in economically developed regions of the world [1-3]. Although traditionally regarded as lymphoma, leukaemia and myeloma, haematological malignancies are, in fact, exceptionally heterogeneous, with the World Health Organisation classification system recognising over 60 different clinical and pathological disease subtypes [4]. This complexity is further reflected in the widely varying clinical features, treatment pathways and outcomes associated with these diseases [5]. Despite recent advances in treatment, survival for some disease

\footnotetext{
* Correspondence: debra.howell@egu.york.ac.uk

1 Epidemiology and Genetics Unit, Department of Health Sciences, Seebohm Rowntree Building, University of York, YO10 5DD, UK

Full list of author information is available at the end of the article
}

subtypes may be poor, and in this context it is clear that good end-of-life care is an issue that is of equal significance as achieving cure [6]. Consequently, research surrounding end-of-life issues and particularly place of death is important, yet despite this, there is a distinct lack of formal research in this area.

It is generally believed that the majority of people, including haematology patients, would prefer to be cared for and die at home [7-9]. In the United Kingdom (UK), the National End of Life Care Programme [10] was launched in 2004, with one of its aims being to ensure individuals have more choice as to where they live and die. Publication of the End of Life Care Strategy [11] brought together initiatives from this programme including Advance Care Planning, Preferred Priorities for Care, the Gold Standards Framework and Liverpool Care Pathway for the Dying Patient, to ensure choice was available 
to patients and so enable them die in their preferred place.

A number of individual studies have examined place of death in patients with haematological malignancies [12$31,48]$. Although these report patients dying in hospital more frequently than those with solid tumours, this has never been formally reviewed. This review systematically examines all studies of place of death in haematology patients and includes a meta-analysis of risk estimates. It also explores factors reported in the wider literature that are considered to lead to hospital deaths in these patients. Finally, further research is suggested, which would improve understanding of end-of-life care and place of death and could also be used to drive change in this complex area.

\section{Methods}

PubMed was searched in January 2009 (with a final search in March 2010) for all studies, in any language, published between 1966 and 2009 and containing the terms 'haematology', 'lymphoma', 'leukaemia', 'myeloma' or 'cancer', combined with 'place of death', 'place of care' or 'end-of-life' in the title, abstract or keywords. PubMed titles were also searched for specific phrases including: 'place of death', 'death in hospital', 'nursing home death', 'hospice death', 'death at home', 'place end of life', 'dying in hospital', 'dying home' and 'dying hospice'.

All identified abstracts were reviewed by two researchers and a scoring system used to select papers meeting specific pre-determined criteria. One point was scored for each of the following: examining place of death; including patients with haematological malignancies; including adults; obtaining information on place of death from routinely compiled morbidity and mortality data; and providing results specific to the haematology patients. References of identified studies were also searched and additional papers included as appropriate. Studies of children $\leq 18$ years were excluded due to the different issues associated with place of death in this age group in terms of disease types, clinical care, associated infrastructure (for example hospice provision) and family support.

The search identified 2,007 published reports (Figure 1). During the screening process, studies scoring 3 or less were excluded from the abstract alone $(\mathrm{n}=1,927)$. Studies scoring 4 or 5 , or with unclear scores (for example if the cancer sites included were not specified in the abstract) were retrieved for scrutiny $(n=80)$. Twenty-four publications meeting all the criteria were selected for final screening and a further 3 were then excluded. This was either because the data appeared elsewhere [32], or the study was in an area where important cultural differences influenced place of death to an extent not found in other settings [33], or data discrepancies were identified mean-

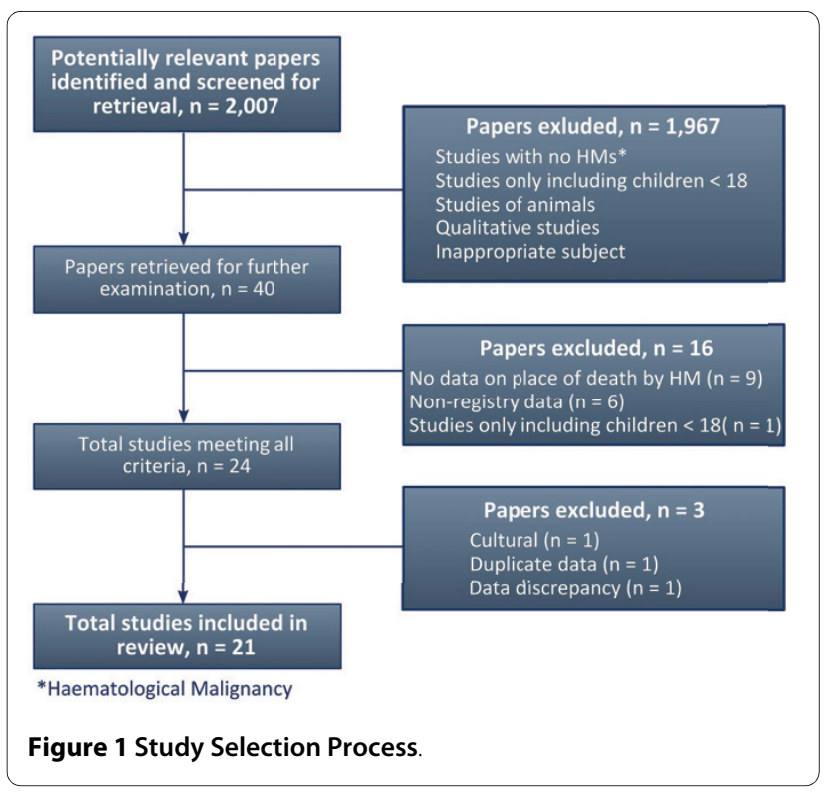

ing that the original published material could not be used [34]. The remaining 21 studies are included in this review; and 17 presented data that could be included in a meta-analysis, one of which gave data for 5 individual countries. This equates to a total of over 30,150 haematology patients - the number of patients was not given in four studies, one of which was included in the meta-analysis [22].

Descriptive data, in terms of the percentage of hospital deaths were extracted for all cancers and for haematological malignancies where given. Risk-estimates for hospital death, with $95 \%$ confidence intervals, were also extracted or calculated if data were amenable. Descriptive data were summarised and a meta-analysis of risk-estimates created using Stata 10.0 Statistical Software, and presented in a meta-plot (Figure 2).

\section{Results}

In comparing haematological malignancies to other cancer deaths, it is evident that haematology patients are more likely to die in hospital (Table 1). As shown in Figure 2 haematology patients are, in fact, more than twice as likely to die in hospital compared to those with other cancers (Odds Ratio 2.25 [95\% Confidence intervals, 2.07-2.44] $\mathrm{p}<0.0001)$. Studies examining death in other areas, such as hospices, also found that those with haematological disease were less likely to die in these places compared to those with other cancers (Table 1) $[20,26,30]$.

Variation was seen in the type of haematological malignancy included in individual studies, with some including several diagnostic categories and others focusing on one particular classification. However, results were again found to be largely consistent across sub-groups. One UK 


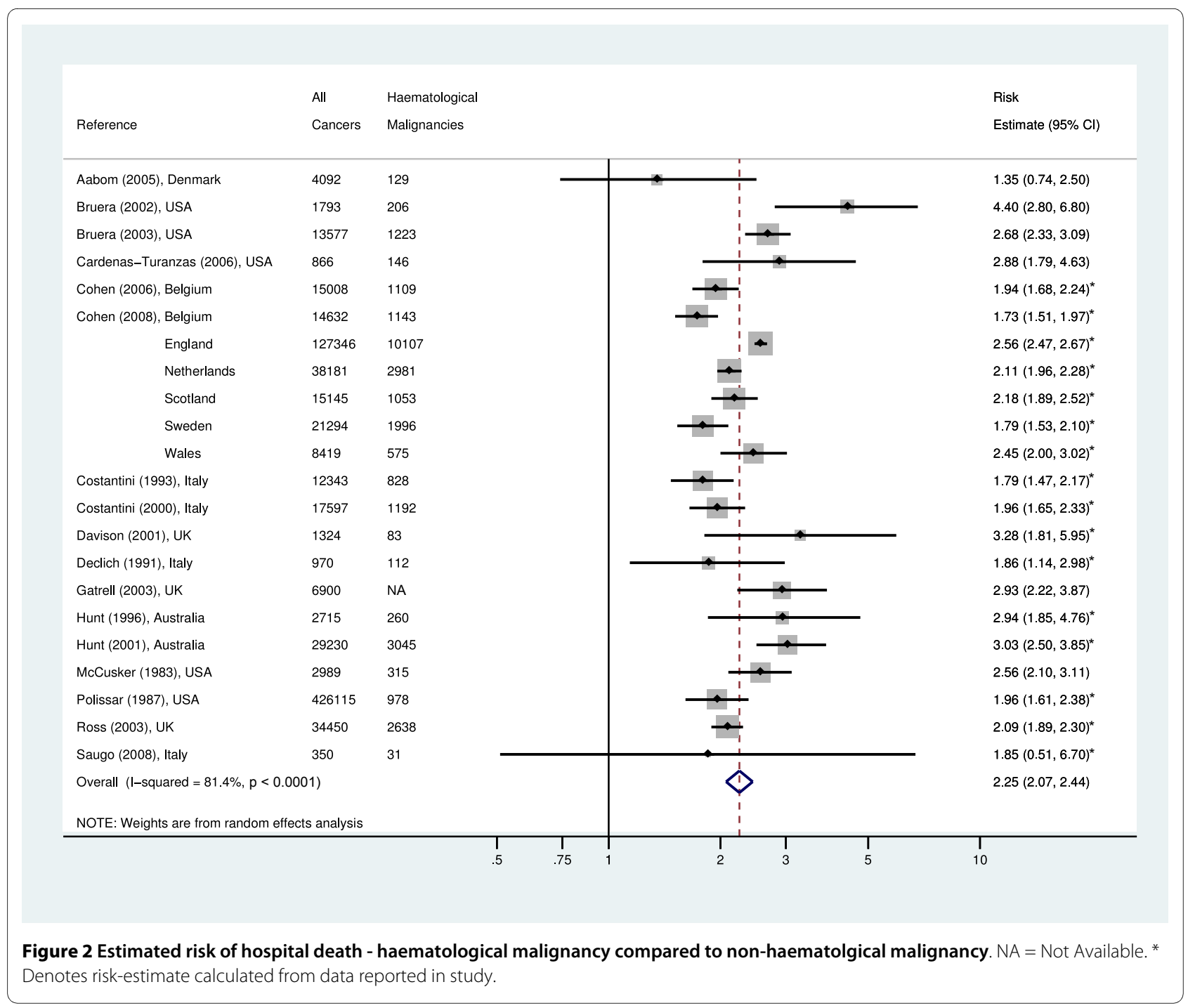

study with a detailed sub-group analysis reported more hospital deaths among all types of haematological malignancy $(62 \%)$ compared to other malignancies (41\%) but with some variation between subgroups [30]. For example, greater proportions of hospital deaths were seen in patients with acute myeloid leukaemia (67\%) and chronic lymphocyte leukaemia (67\%). Interestingly, the proportion of patients with acute lymphoblastic leukaemia dying at home (31\%) was similar to that seen for other cancers (30\%), as was the proportion with Hodgkin lymphoma (27\%).

\section{Discussion}

It is a challenging yet opportune time for practitioners delivering end-of-life care, especially in the UK where there is a drive to enable patients to be cared for and die in the place of their choice. Our review clearly illustrates that the majority of patients with a haematological malignancy die in hospital. They are in fact more than twice as likely to die in hospital as those with other cancers. Studies mostly originated from within Europe, the USA and Australia and findings were generally consistent across these areas. Given that home is usually considered to be the preferred place of death $[7,8]$, this has implications for both patients, who may not be dying in their preferred place, and also health commissioners, who may be funding costly end-of-life care in inappropriate, acute hospital settings.

In order to ensure haematology patients receive appropriate end-of-life care, and are enabled to die in their preferred place, it is crucial that an evidence base is established so that existing practices can be defined and evaluated. In terms of understanding why hospital deaths are so common, current explanations are often derived from anecdote, case studies or qualitative research studies. Factors cited as leading to hospital death often include the complex transition from an active or curative approach to a palliative approach to care - a transition 
Table 1: Summary of reported findings and proportion of hospital deaths for all cancers and haematological malignancies.

\begin{tabular}{|c|c|c|c|c|c|}
\hline \multirow[t]{2}{*}{ Study } & \multirow[t]{2}{*}{ Country } & \multirow{2}{*}{$\begin{array}{l}\text { Dates of } \\
\text { deaths }\end{array}$} & \multicolumn{2}{|c|}{ Total patients (\% hospital deaths) } & \multirow[t]{2}{*}{ Main findings } \\
\hline & & & All cancers & $\begin{array}{l}\text { Haematological } \\
\text { malignancy }\end{array}$ & \\
\hline Aabom, $2005[12]^{*}$ & Denmark & $01 / 96-12 / 98$ & $4,092(70)$ & $129(84)$ & $\begin{array}{l}\text { Compared to all other cancer deaths, } \\
\text { patients dying from 'haematological' } \\
\text { cancers (coding not specified) were } \\
\text { more likely to die in institutions } \\
\text { (hospital/nursing home). }\end{array}$ \\
\hline Bruera, $2002[13]^{*}$ & USA & 09/97-08/98 & $1,466(57)$ & $206(84)$ & $\begin{array}{l}\text { Compared to all other cancer deaths, } \\
\text { patients dying from 'hematologic' } \\
\text { (coding not specified) were more likely } \\
\text { to die in hospital. }\end{array}$ \\
\hline Bruera, $2003[14]^{*}$ & USA & 09/96-08/98 & $13,577(51)$ & 1,223 (NA) & $\begin{array}{l}\text { Compared to all other cancer deaths, } \\
\text { patients dying from 'haematological' } \\
\text { cancers (coding not specified) were } \\
\text { more likely to die in hospital. }\end{array}$ \\
\hline $\begin{array}{c}\text { Cardenas-Turanzas, } \\
2006[15]^{*}\end{array}$ & USA & $1999-2000$ & $866(58)$ & $146(79)$ & $\begin{array}{l}\text { Compared to all other cancer deaths, } \\
\text { patients dying from 'leukaemia and } \\
\text { lymphoma' were more likely to die in } \\
\text { hospital than elsewhere (home/nursing } \\
\text { home/hospice). }\end{array}$ \\
\hline Cohen, $2006[16]^{*}$ & Belgium & 2001 & $15,0008(54)$ & $1,109(75)$ & $\begin{array}{l}\text { Compared to all other cancer deaths, } \\
\text { patients dying from 'hematologic' } \\
\text { cancers were more likely to die in } \\
\text { hospital than home/care home/ } \\
\text { elsewhere. }\end{array}$ \\
\hline${ }^{1}$ Cohen, $2008[17]$ * & $\begin{array}{l}\text { Belgium } \\
\text { Netherlands } \\
\text { Sweden } \\
\text { Scotland } \\
\text { England } \\
\text { Wales }\end{array}$ & $\begin{array}{l}2003 \\
2003 \\
2002 \\
2003 \\
2003 \\
2003\end{array}$ & $\begin{array}{l}14,632(59) \\
38,181(31) \\
21,294(85) \\
15,145(57) \\
127,346(49) \\
8,419(60)\end{array}$ & $\begin{array}{c}1,143(71) \\
2,981(47) \\
1,996(91) \\
1,053(74) \\
10,107(70) \\
575(78)\end{array}$ & $\begin{array}{l}\text { Compared to all other cancer deaths, } \\
\text { patients dying from 'hematologic } \\
\text { malignancies' were more likely to die in } \\
\text { hospital/care home than outside } \\
\text { hospital. This was consistent across all } \\
\text { countries included. }\end{array}$ \\
\hline Costantini, $1993[18]^{*}$ & Italy & $01 / 86-12 / 90$ & $12,315(69)$ & $828(79)$ & $\begin{array}{l}\text { Compared to all other cancer deaths, } \\
\text { patients dying from 'leukaemia- } \\
\text { lymphoma' were more likely to die in an } \\
\text { institution (hospital/elderly care home). }\end{array}$ \\
\hline Costantini, $2000[19]^{*}$ & Italy & 1991 & $17,597(48)$ & $1,192(64)$ & $\begin{array}{l}\text { Compared to all other specified cancer } \\
\text { deaths, patients dying from cancers of } \\
\text { the 'haemopoietic system' were more } \\
\text { likely to die in a hospital/elderly care } \\
\text { home. }\end{array}$ \\
\hline Davison, $2001[20]^{*}$ & UK & $\begin{array}{c}\text { July-Dec } \\
\text { 1977/87/97 }\end{array}$ & $1,324(47)$ & $83(75)$ & $\begin{array}{l}\text { Compared to all other cancer deaths, } \\
\text { patients dying from cancer of the } \\
\text { 'lymphatic' and 'haemopoietic tissue' } \\
\text { were more likely to die in hospital and } \\
\text { less likely to die in a hospice. }\end{array}$ \\
\hline
\end{tabular}


Table 1: Summary of reported findings and proportion of hospital deaths for all cancers and haematological malignancies. (Continued)

\begin{tabular}{|c|c|c|c|c|c|}
\hline Declich, 1991 [21] $^{*}$ & Italy & $01 / 85-12 / 88$ & $970(18)$ & $112(27)$ & $\begin{array}{l}\text { Compared to all other cancer deaths, } \\
\text { patients dying from 'lymphoma' and } \\
\text { 'haematopoietic neoplasms' were more } \\
\text { likely to die in hospital (with the } \\
\text { exception of colon cancer). }\end{array}$ \\
\hline
\end{tabular}

\begin{tabular}{cccc}
\hline Decker, 2006 [48] UK/USA $1995-1998 \quad$ UK 59,604 (56) USA & $51,668(74)$ & NA & $\begin{array}{l}\text { Compared to all other cancer deaths, } \\
\text { patients dying from cancer of the } \\
\text { 'lymphatic' and 'haematopoietic' tissue } \\
\text { aged } \geq 40 \text { years were less likely to die at } \\
\text { home (12\% UK; } 14 \% \text { USA). }\end{array}$
\end{tabular}

\begin{tabular}{|c|c|c|c|c|c|}
\hline Gatrell, $2003[22]^{*}$ & UK & $1993-2000$ & $6,900(35)$ & NA & $\begin{array}{l}\text { Compared to all other cancer deaths, } \\
\text { patients dying from 'lymphatic system' } \\
\text { cancer were more likely to die in } \\
\text { hospital. }\end{array}$ \\
\hline Higginson, 1998 [23] & UK & 1985-1994 & $1,344,187(66)$ & NA & $\begin{array}{l}\text { Compared to all other cancer deaths, } \\
\text { patients dying from cancers of the } \\
\text { 'lymphatic' or 'haematological system' } \\
\text { were less likely to die at home. }\end{array}$ \\
\hline
\end{tabular}

\begin{tabular}{|c|c|c|c|c|c|}
\hline Hunt, $1996[24]^{*}$ & Australia & 1990 & $2,800(\mathrm{NA})$ & 260 (NA) & $\begin{array}{l}\text { Compared to all other cancer deaths, } \\
\text { patients dying from 'haematological' } \\
\text { cancers (coding not specified) were } \\
\text { more likely to die in a Metropolitan } \\
\text { Public Hospital. }\end{array}$ \\
\hline Hunt, $2001[25]^{*}$ & Australia & 1990-1999 & $29,230(55)$ & 3,045 (NA) & $\begin{array}{l}\text { Compared to all other cancer deaths, } \\
\text { patients dying from 'lymphoma', } \\
\text { 'multiple myeloma' and 'leukaemias' } \\
\text { (coding not specified) were more likely } \\
\text { to die in a Metropolitan Public Hospital. }\end{array}$ \\
\hline Lock, 2005 [26] & UK & 1995-1999 & $315,462(50)$ & NA (66) & $\begin{array}{l}\text { Compared to all other cancer deaths, } \\
\text { patients dying from 'lymphatic' and } \\
\text { 'haematopoietic' cancers aged } \geq 75 \\
\text { years, were more likely to die in hospital } \\
\text { and less likely to die in a hospice. }\end{array}$ \\
\hline McCusker, $1983[27]^{*}$ & USA & 1976-1978 & $2,989(70)$ & $315(82)$ & $\begin{array}{l}\text { Compared to all other cancer deaths, } \\
\text { patients dying from 'leukaemia and } \\
\text { lymphoma' (coding not specified) were } \\
\text { more likely to die in an acute care } \\
\text { hospital. }\end{array}$ \\
\hline Polissar, 1987 [28]* & USA & 1968-1981 & $22,456(61)$ & $978(73)$ & $\begin{array}{l}\text { Compared to other common cancers ( } 9 \\
\text { selected cancer sites) patients with 'non- } \\
\text { Hodgkin lymphoma' were the most likely } \\
\text { to die in hospital. }\end{array}$ \\
\hline Roder, 1987 [29] & Australia & $1981 \& 1985$ & $1,582(37)$ & NA (57) & $\begin{array}{l}\text { Compared to other common cancers ( } 8 \\
\text { selected sites), patients with } \\
\text { 'haematological malignancies' } \\
\text { (leukaemia, lymphoma and myeloma) } \\
\text { were more likely to die in a Metropolitan } \\
\text { Public Hospital. }\end{array}$ \\
\hline
\end{tabular}


Table 1: Summary of reported findings and proportion of hospital deaths for all cancers and haematological malignancies. (Continued)

\begin{tabular}{|c|c|c|c|c|c|}
\hline Ross, $2007[30]^{*}$ & UK & $1995-2000$ & $31,812(41)$ & $2,638(62)$ & $\begin{array}{l}\text { Compared to all other cancer deaths, } \\
\text { patients dying from haematological } \\
\text { malignancy (all diagnoses combined) } \\
\text { were more likely to die in hospital and } \\
\text { less likely to die in a hospice. }\end{array}$ \\
\hline Saugo, $2008[31]^{*}$ & Italy & 2004 & $350(75)$ & $31(87)$ & $\begin{array}{l}\text { Compared to all other cancer deaths, } \\
\text { patients dying from 'haematological' } \\
\text { cancers } \geq 50 \text { years were more likely to die } \\
\text { in hospital. }\end{array}$ \\
\hline
\end{tabular}

which is not always clear in haematology [6,35-38]. This lack of clarity can arise because some haematological diseases, such as myeloma and follicular lymphoma are considered incurable from diagnosis; thus all treatments, although having the potential to substantially prolong life, are essentially given with palliative intent from the outset. The situation is further complicated by the increasing number of salvage therapies available to patients, resulting in continued treatment even in the very late stages of disease, a situation which may give rise to sentiments of denial or the continued hope of a response, both in patients and practitioners [13,36,39].

In the UK, initiatives such as Advanced Care Planning, Preferred Priorities for Care and the Gold Standards Framework [11] aim to provide patients with the opportunity to discuss the place of their death and plan where they would prefer this to happen. However, the patient pathway associated with haematological malignancy is recognised as being complex and uncertain, with death sometimes occurring suddenly, unexpectedly, or very rapidly after diagnosis [26,39-41]. Also, certain treatments, such as allogeneic bone marrow transplantations, can be associated with a rapid change in the focus of care from curative to palliative [42]. In contexts such as these the opportunity to discuss place of death may not arise, or may even be inappropriate. Such situations may lead to difficulties estimating prognosis and concerns about the inappropriate early withdrawal of treatment [38]. Failure to recognise and respond to this transition may, however, lead to a crisis management situation and an inappropriate emergency hospital admission [41].

Further factors influencing place of death are the disease symptoms and the side effects of chemotherapy, which our previous work on patient pathways has shown can be intensive and prolonged [5]. The possibility of complicating factors, including anaemia, bleeding and infection, can result in the need for ongoing transfusion of blood products, antibiotic and antifungal medication, which may require long term hospitalisation, with death in acute or intensive care settings often being reported $[13,32,35,36,43]$.

In some situations, an excess of hospital deaths among haematological malignancy patients has been suggested to reflect the fact that haematologists have limited links with palliative care services. This lack of integration has been recognised as a particular problem in Australia, $[6,38,39,44,45]$ and has led to the UK [46] making recommendations to promote links between these specialities. However, because of the nature of their condition, haematology patients are known to have a sustained and intense relationship with their haematology team $[22,32,41]$. Indeed, unlike patients with other types of cancer, those in haematology are often managed throughout the entire course of their illness, including the terminal phase, within haematology [30]. Whilst this close association may explain the apparent lack of palliative care involvement it could also result in patients having difficulty accessing community palliative care services or hospice facilities - a situation which may lead to an inappropriate acute hospital admission for terminal care and ultimately death [41].

Our review indicated a dearth of empirical research exploring these issues, in particular the factors and circumstances either leading to emergency hospital admission at the end-of-life, or preventing hospital discharge and the delivery of end-of-life care at home. This may for example include a better understanding of the degree to which dependence on blood product transfusions exists and potential alternatives to receiving these products in hospital [41]. Clearly, further work exploring the complexity and duration of the patient pathway, variations in the type and intensity of treatment and the transition from active, life prolonging to palliative care would lead to better understanding of end-of-life issues among haematology patients.

End-of-life care is a complex, multi-disciplinary and indeed multi-dimensional concept, with many interrelated themes that cannot be considered in isolation [47]. 
It includes the provision of care by multiple practitioners (for example, clinicians and nurse specialists in haematology, palliative care and other medical specialities); liaison and interaction between different settings (primary and secondary care, out of hours care, social care, care homes and hospices) and services (NHS, voluntary and local authority). Thus a greater understanding is also needed about the broader organisation, management and delivery of end-of-life care for haematology patients. More information is also needed about potential limiting factors, such as a lack of community facilities and resources including hospice places, community staff, equipment or training. Importantly, variations in place of death by haematological subtype [30] emphasise the need to further explore these differences by specific disease classifications.

Although existing research indicates that preferred place of death is often home, it is important to recognise that currently there is no empirical evidence to support this in haematology and again this is an area where more research is needed. If, as the literature suggests, patients develop a strong relationship with their clinical haematology team over the duration of their illness, and hospital is regarded as a place where they feel secure and are most likely to receive prompt medical attention, then hospital may indeed be the preferred place of place of care and death for some. Further research with patients and carers is needed to develop detailed, clearer insight into these issues.

\section{Conclusion}

Home is generally considered the preferred place of death but haematology patients usually die in hospital. This has implications for patients who may not be dying where they wish, and also health commissioners who may be funding costly end-of-life care in inappropriate acute hospital settings. More research is needed about preferred place of care for haematology patients, reasons for hospital deaths, and how these can be avoided if home death is preferred.

\section{Competing interests}

The authors declare that they have no competing interests.

\section{Authors' contributions}

The Palliative Care and Haematological Malignancy Steering Committee had the original idea for the review. DH managed the review, conducted the search, retrieved, scored and performed the final screening of studies, extracted data and wrote the manuscript. HC independently second-scored the studies. ER and AS performed the final screening of studies, extracted data and calculated risk estimates. All authors commented on the final version of the manuscript.

\section{Acknowledgements}

We would like to acknowledge members of the Palliative Care and Haematological Malignancy Steering Committee who contributed to many discussions on this subject with the authors: in particular Pat Ansell, David Brown, Shirley Fraser, Deborah Johnson, David Mazza and Janet Munro. This work is part of an ongoing portfolio of studies examining palliative care in haematological malignancy, which has been possible due to funding from Leukaemia and Lym- phoma Research and a patient legacy left to the Department of Haematology at York Hospital. We are grateful to Eleanor Kane for producing the meta-analysis plot and John Blase for editing the Figures.

\section{Author Details}

'Epidemiology and Genetics Unit, Department of Health Sciences, Seebohm Rowntree Building, University of York, YO10 5DD, UK, 2Department of Haematology, Queens Centre for Oncology and Haematology, Castle Hill Hospital, Castle Road, Cottingham, East Yorkshire, HU16 5JQ, UK, 3Palliative Medicine, North Yorkshire and York PCT, York, YO31 8HE, UK and 4 Department of Haematology, York Hospital, Wigginton Road, York, YO31 8HE, UK

Received: 18 January 2010 Accepted: 1 June 2010

Published: 1 June 2010

\section{References}

1. Ferlay J, Bray F, Pisani P, Parkin DM, GLOBOCAN 2002: Cancer Incidence, Mortality and Prevalence Worldwide 5th edition. Lyon, IARC Press; 2004.

2. Jemal A, Siegel R, Ward E, Hao Y, Xu J, Murray T, Thun M: Cancer statistics, 2008. CA Cancer J Clin 2008, 58:71-96.

3. Westlake S: Cancer incidence and mortality in the United Kingdom and constituent countries, 2003-05. Health Stat Q 2008:91-97.

4. Jaffe ES, Harris NL, Stein H, Vardiman JW, (Eds): World Health Organisation Classification of Tumours. Pathology and Genetics of Tumours of Haematopoietic and Lymphoid Tissues Lyon: IARC Press; 2001.

5. Smith A, Roman E, Howell D, Jones R, Patmore R, Jack A: The Haematological Malignancy Research Network (HMRN): a new information strategy for population based epidemiology and health service research. Br J Haematol 2009.

6. McGrath P: Palliative care for patients with hematological malignancies--if not, why not? J Palliat Care 1999, 15:24-30.

7. Higginson IJ: Priorities and preferences for end of life care. The Cicely Saunders Foundation Scottish Parnership for Palliative Care and National Council for Hospice and Specialist Palliative Care Services; 2003.

8. Higginson IJ, Sen-Gupta GJ: Place of care in advanced cancer: a qualitative systematic literature review of patient preferences. J Palliat Med 2000, 3:287-300.

9. McGrath P: Dying in the curative system: the haematology/oncology dilemma. Part 1. Aust J Holist Nurs 2001, 8:22-30.

10. Department of Health: National End of Life Care Programme. 2009 [http://www.endoflifecareforadults.nhs.uk/eolc/index.htm]. Nationa Health Service, UK

11. Department of Health: End of Life Care Strategy - Promoting High Quality Care for all Adults at the End of Life. COl for the Department of Health; 2008.

12. Aabom B, Kragstrup J, Vondeling H, Bakketeig LS, Stovring H: Populationbased study of place of death of patients with cancer: implications for GPs. Br J Gen Pract 2005, 55:684-689.

13. Bruera E, Russell N, Sweeney C, Fisch M, Palmer JL: Place of death and its predictors for local patients registered at a comprehensive cancer center. J Clin Oncol 2002, 20:2127-2133.

14. Bruera E, Sweeney C, Russell N, Willey JS, Palmer JL: Place of death of Houston area residents with cancer over a two-year period. J Pain Symptom Manage 2003, 26:637-643.

15. Cardenas-Turanzas M, Grimes RM, Bruera E, Quill B, Tortolero-Luna G: Clinical, sociodemographic, and local system factors associated with a hospital death among cancer patients. Support Care Cancer 2006, 14:71-77.

16. Cohen J, Bilsen J, Hooft P, Deboosere P, van der Wal G, Deliens L: Dying at home or in an institution using death certificates to explore the factors associated with place of death. Health Policy 2006, 78:319-329.

17. Cohen J, Bilsen J, Addington-Hall J, Lofmark R, Miccinesi G, Kaasa S, Onwuteaka-Philipsen B, Deliens L: Population-based study of dying in hospital in six European countries. Palliat Med 2008, 22:702-710.

18. Costantini M, Camoirano E, Madeddu L, Bruzzi P, Verganelli E, Henriquet F: Palliative home care and place of death among cancer patients: a population-based study. Palliat Med 1993, 7:323-331.

19. Costantini M, Balzi D, Garronec E, Orlandini C, Parodi S, Vercelli M, Bruzzi P: Geographical variations of place of death among Italian communities suggest an inappropriate hospital use in the terminal phase of cancer disease. Public Health 2000, 114:15-20.

20. Davison D, Johnston G, Reilly P, Stevenson M: Where do patients with cancer die in Belfast? Ir J Med Sci 2001, 170:18-23. 
21. Declich P, Duca PG, Galli C, Turolla E: Selection for necropsy: evaluation of 321 autopsied cases from 3041 consecutive deaths among residents of a defined geographical area. IARC Sci Pub/ 1991:223-233.

22. Gatrell AC, Harman JC, Francis BJ, Thomas C, Morris SM, McIllmurray M: Place of death: analysis of cancer deaths in part of North West England. J Public Health Med 2003, 25:53-58.

23. Higginson IJ, Astin P, Dolan S: Where do cancer patients die? Ten-year trends in the place of death of cancer patients in England. Palliat Med 1998, 12:353-363.

24. Hunt R, McCaul K: A population-based study of the coverage of cancer patients by hospice services. Palliat Med 1996, 10:5-12.

25. Hunt RW, Fazekas BS, Luke CG, Roder DM: Where patients with cancer die in South Australia, 1990-1999: a population-based review. Med J Aust 2001, 175:526-529.

26. Lock A, Higginson I: Patterns and predictors of place of cancer death for the oldest old. BMC Palliat Care 2005, 4:6.

27. McCusker J: Where cancer patients die: an epidemiologic study. Public Health Rep 1983, 98:170-176.

28. Polissar L, Severson RK, Brown NK: Factors affecting place of death in Washington State, 1968-1981. J Community Health 1987, 12:40-55.

29. Roder D, Bonett A, Hunt R, Beare M: Where patients with cancer die in South Australia. Med J Aust 1987, 147:11-13.

30. Ross J, Watters A, Roche MF: Place of death in patients with haematological malignancy. British Journal of Haematology 2007, 121(Supplement):55.

31. Saugo M, Pellizzari M, Marcon L, Benetollo P, Toffanin R, Gallina P, Cecchetto G, Miccinesi G, Rigon S, Cancian M, Sichetti D: Impact of home care on place of death, access to emergency departments and opioid therapy in 350 terminal cancer patients. Tumori 2008, 94:87-95.

32. Hunt R, Bonett A, Roder D: Trends in the terminal care of cancer patients: South Australia, 1981-1990. Aust NZ J Med 1993, 23:245-251.

33. Lin HC, Lin CC: A population-based study on the specific locations of cancer deaths in Taiwan, 1997-2003. Support Care Cancer 2007, 15:1333-1339

34. Cardenas-Turanzas M, Carrillo MT, Tovalin-Ahumada H, Elting L: Factors associated with place of death of cancer patients in the Mexico City Metropolitan area. Support Care Cancer 2007, 15:243-249.

35. Middlewood S, Gardner G, Gardner A: Dying in hospital: medical failure or natural outcome? J Pain Symptom Manage 2001, 22:1035-1041.

36. Ansell P, Howell D, Garry A, Kite S, Munro J, Roman E, Howard M: What determines referral of UK patients with haematological malignancies to palliative care services? An exploratory study using hospital records. Palliat Med 2007, 21:487-492

37. Joske D, McGrath P: Palliative care in haematology. Intern Med J 2007, 37:589-590.

38. Auret K, Bulsara C, Joske D: Australasian haematologist referral patterns to palliative care: lack of consensus on when and why. Intern Med J 2003, 33:566-571.

39. McGrath P: Are we making progress? Not in haematology! Omega (Westport) 2002, 45:331-348.

40. McGrath P, Holewa H: Special considerations for haematology patients in relation to end-of-life care: Australian findings. Eur J Cancer Care (Engl) 2007, 16:164-171.

41. Boyce $A$, McHugh M, Lyon P: Proactive palliative care choices for haematology day unit patients. Int J Palliat Nurs 2003, 9:544-550.

42. Mander T: Haematology and palliative care: an account of shared care for a patient undergoing bone marrow transplantation for chronic myeloid leukaemia. Int J Nurs Pract 1997, 3:62-66.

43. Stalfelt AM, Brodin H, Pettersson S, Eklof A: The final phase in acute myeloid leukaemia (AML): a study of cause of death, place of death and type of care during the last week of life. Leuk Res 2001, 25:673-680

44. Maddocks I, Bentley L, Sheedy J: Quality of life issues in patients dying from haematological diseases. Ann Acad Med Singapore 1994, 23:244-248.

45. McGrath P, Holewa H: Missed opportunities: nursing insights on end-oflife care for haematology patients. Int J Nurs Pract 2006, 12:295-301.

46. National Institute for Clinical Excellence: Improving Outcomes in Haematological Cancers: The Manual. London, National Institute for Clinical Excellence:3

47. Higginson IJ, Shipman C, Gysels M, White P, Barclay S, Forrest S: Scoping exercise on generalist services for adults at the end of life: research, knowledge, policy and future research needs Report 1: Overview and recommendations for future research in generalist end of life care. London, NCCSDO. Report for the NIHR Service Delivery Organisation Programme; 2007

48. Decker SL, Higginson IJ: A tale of two cities: Factors affecting place of cancer death in London and New York. Eur J Public Health 2006.

\section{Pre-publication history}

The pre-publication history for this paper can be accessed here: http://www.biomedcentral.com/1472-684X/9/9/prepub

doi: $10.1186 / 1472-684 X-9-9$

Cite this article as: Howell et al., Destined to die in hospital? Systematic review and meta-analysis of place of death in haematological malignancy BMC Palliative Care 2010, 9:9

\section{Submit your next manuscript to BioMed Central and take full advantage of:}

- Convenient online submission

- Thorough peer review

- No space constraints or color figure charges

- Immediate publication on acceptance

- Inclusion in PubMed, CAS, Scopus and Google Scholar

- Research which is freely available for redistribution

Submit your manuscript at www.biomedcentral.com/submit
C) Biomed Central 